\title{
Deaths of Health Workers at Prof. Dr. R. D. Kandou Hospital Exposed to Coronavirus Disease-19 Period 2020-2021
}

Kematian Tenaga Kesehatan RSUP Prof. Dr. R. D. Kandou yang Terpapar Coronavirus Disease-19 Periode 2020 - 2021

\author{
Reinhart E. Sunardibuana, ${ }^{1}$ Johannis F. Mallo, ${ }^{2}$ James F. Siwu \\ ${ }^{1}$ Program Studi Pendidikan Dokter Fakultas Kedokteran Universitas Sam Ratulangi Manado, \\ Indonesia \\ ${ }^{2}$ Bagian Ilmu Kedokteran Forensik Fakultas Kedokteran Universitas Sam Ratulangi Manado, \\ Indonesia \\ E-mail: reinhart.ebenhaezer@gmail.com \\ Received: December 22, 2021; Accepted: February 9, 2022; Published on line: February 10, 2022
}

\begin{abstract}
Coronavirus disease-19 (COVID-19) pandemic has spread to all countries, including Indonesia. This pandemic has caused a lot of losses in economic factors as well as losses of relatives including health care workers. This study aimed to determine the description of deaths among health care workers at Prof. Dr. R. D. Kandou Hospital, Manado, who were exposed to COVID-19. This was a retrospective and descriptive study using secondary data, namely all deaths of health care workers at Prof. Dr. R. D. Kandou Hospital exposed to COVID-19 in the period of 2020-2021. The results showed that there were four cases of deaths among health care workers at Prof. Dr. R. D. Kandou Hospital exposed to COVID-19 during the period 20202021. Three cases were over 55 years old and one case was between 25-55 years old. Three cases were male and one case was female. Four cases were medical personnel (general practitioners and specialists). Four cases had hypertension, three cases had diabetes, and one case had heart disease as comorbid. In conclusion, from the health workers at Prof. Dr. R. D. Kandou Hospital exposed to COVID-19, the majority of deaths occurred in males, aged over 55 years, medical personnel, and had hypertension as comorbid.
\end{abstract}

Keywords: mortality; health care workers; coronavirus disease-19

\begin{abstract}
Abstrak: Pandemi coronavirus disease-19 (COVID-19) melanda semua negara, termasuk Negara Indonesia. Pandemi ini menyebabkan banyak kerugian, dari faktor ekonomi hingga kehilangan kerabat termasuk tenaga kesehatan. Penelitian ini bertujuan untuk mendapatkan gambaran kematian tenaga kesehatan RSUP Prof. Dr. R. D. Kandou Manado yang terpapar COVID-19. Jenis penelitian ialah deskriptif retrospektif dengan menggunakan data sekunder, yaitu seluruh data kematian tenaga kesehatan RSUP Prof. Dr. R. D. Kandou Manado yang terpapar COVID-19 periode 2020-2021. Hasil penelitian mendapatkan empat kasus kematian pada tenaga kesehatan RSUP Prof. Dr. R. D. Kandou Manado yang terpapar COVID-19 selama periode 2020-2021 yaitu tiga kasus berusia di atas 55 tahun dan satu kasus berusia di antara 2555 tahun. Terdapat tiga kasus berjenis kelamin laki-laki dan satu kasus berjenis kelamin perempuan; kesemuanya ialah tenaga medis (dokter umum dan dokter spesialis). Empat kasus dengan komorbid hipertensi, tiga kasus dengan komorbid diabetes, dan satu kasus dengan komorbid penyakit jantung. Simpulan penelitian ini ialah pada tenaga kesehatan RSUP Prof. Dr. R. D. Kandou Manado yang terpapar COVID-19, mayoritas kematian terjadi pada laki-laki, berusia di atas 55 tahun, tenaga medis, dengan komorbid hipertensi.
\end{abstract}

Kata kunci: mortalitas; tenaga kesehatan; coronavirus disease-19 


\section{PENDAHULUAN}

Pada saat ini, sebuah pandemi sedang melanda seluruh dunia dan juga Negara Indonesia, yaitu pandemi Coronavirus Disease19 (COVID-19). Pada bulan Desember 2019, COVID-19 ditemukan pertama kali di kota Wuhan, Cina dan kemudian menyebar ke semua negara. ${ }^{1}$ World Health Organization (WHO) menetapkan COVID-19 sebagai pandemi global pada tanggal 11 Maret 2020 . $^{2}$ Hingga saat ini terdapat lebih dari 271 juta kasus dan jumlah kematian lebih dari 5 juta kasus. $^{3}$

Kasus COVID-19 di Indonesia pertama kali ditemukan pada tanggal 2 Maret 2020 di kota Depok, ${ }^{4}$ dan kemudian menyebar ke seluruh Indonesia. Saat ini terdapat lebih dari 4 juta kasus COVID-19 terkonfirmasi dan lebih dari 128 ribu kasus kematian. Di antara kasus kematian COVID-19 tersebut, terdapat 1.459 tenaga kesehatan yang meninggal karena COVID-19 dan didominasi oleh dokter sebanyak 545 kasus kematian. ${ }^{5}$

Menurut penelitian yang dilakukan di RSUD Bhakti Dharma Husada Surabaya, komorbid terbanyak pada kasus kematian COVID-19 ialah diabetes dan penyakit jantung. ${ }^{6}$ Penelitian serupa juga dilakukan di Kota Jakarta Timur dengan hasil komorbid tertinggi ialah hipertensi dan gagal ginjal kronik. $^{7}$

Kurangnya laporna penelitian mengenai kejadian COVID-19 pada tenaga kesehatan memotivasi penulis untuk melakukan penelitian mengenai gambaran kematian tenaga kesehatan RSUP Prof. Dr. R. D. Kandou Manado yang terpapar COVID-19 periode 2020-2021.

\section{METODE PENELITIAN}

Metode penelitian yang digunakan pada penelitian ini ialah penelitian deskriptif retrospektif. Penelitian ini menggunakan data sekunder berupa riwayat penyakit pada rekam medis tenaga kesehatan RSUP Prof. Dr. R. D. Kandou Manado yang meninggal terpapar COVID-19 periode 2020-2021. Penelitian ini dilakukan di Instalasi Rekam Medik RSUP Prof. Dr. R. D. Kandou Manado. Sampel penelitian ini menggunakan semua data kematian tenaga kesehatan
RSUP Prof. Dr. R. D. Kandou Manado yang terpapar COVID-19 periode 2020-2021. Variabel penelitian ini ialah jenis kelamin, kelompok usia, kategori kesehatan, dan komorbid dari kasus yang ada.

Penelitian ini telah mendapat persetujuan dari Komisi Etik Penelitian Kesehatan RSUP Prof. Dr. R. D. Kandou Manado dengan nomor surat keterangan layak etik No. 188/EC/KEPK-KANDOU/XI/2021.

\section{HASIL PENELITIAN}

Hasil penelitian ini mendapatkan empat kasus kematian tenaga kesehatan RSUP Prof. Dr. R. D. Kandou Manado yang terpapar COVID-19; dua kasus di tahun 2020 dan dua kasus di tahun 2021.

Tabel 1 memperlihatkan data jumlah kasus kematian tenaga Kesehatan RSUP Prof. Dr. R. D. Kandou Manado yang terpapar COVID-19 berdasarkan kelompok usia. Untuk kelompok usia di bawah 25 tahun tidak terdapat kasus (0\%); kelompok usia 25 sampai 55 tahun terdapat satu kasus (25\%), dan kelompok usia di atas 55 tahun terdapat tiga kasus (75\%). Hal ini menggambarkan bahwa mayoritas tenaga kesehatan yang meninggal berusia di atas 55 tahun.

Tabel 1. Jumlah kematian tenaga kesehatan RSUP Prof. Dr. R. D. Kandou Manado yang terpapar COVID-19 periode 2020-2021 menurut kelompok usia

\begin{tabular}{ccc}
\hline Kelompok usia & Jumlah & \% \\
\hline$<25$ tahun & 0 & 0 \\
$25-55$ tahun & 1 & 25 \\
$>55$ tahun & 3 & 75 \\
\hline
\end{tabular}

Tabel 2 memperlihatkan data jumlah kasus kematian tenaga kesehatan RSUP Prof. Dr. R. D. Kandou Manado yang terpapar COVID-19 berdasarkan jenis kelamin. Untuk jenis kelamin laki-laki sebanyak tiga kasus $(75 \%)$ dan perempuan sebanyak satu kasus $(25 \%)$.

Tabel 3 memperlihatkan bahwa jumlah kasus kematian tenaga kesehatan RSUP Prof. Dr. R. D. Kandou Manado yang terpapar COVID-19 berdasarkan kategori tenaga kesehatan hanya terdapat pada tenaga kese- 
hatan medis sebanyak empat kasus (100\%).

Tabel 2. Jumlah kematian tenaga kesehatan RSUP Prof. Dr. R. D. Kandou Manado yang terpapar COVID-19 periode 2020-2021 menurut jenis kelamin

\begin{tabular}{ccc}
\hline Jenis kelamin & Jumlah & \% \\
\hline Laki-laki & 3 & 75 \\
Perempuan & 1 & 25 \\
\hline
\end{tabular}

Tabel 3. Jumlah kematian tenaga kesehatan RSUP Prof. Dr. R. D. Kandou Manado yang terpapar COVID-19 periode 2020 -2021 menurut kategori tenaga kesehatan

\begin{tabular}{lcc}
\hline \multicolumn{1}{c}{ Tenaga Kesehatan } & Jumlah & \% \\
\hline Medis & 4 & 100 \\
Psikologi Klinis & 0 & 0 \\
Keperawatan & 0 & 0 \\
Kebidanan & 0 & 0 \\
Kefarmasian & 0 & 0 \\
Kesehatan Masyarakat & 0 & 0 \\
Kesehatan Lingkungan & 0 & 0 \\
Gizi & 0 & 0 \\
Keterapian Fisik & 0 & 0 \\
Keteknisian Medis & 0 & 0 \\
Teknik Biomedika & 0 & 0 \\
Kesehatan Tradisional & 0 & 0 \\
\hline
\end{tabular}

Tabel 4 memperlihatkan bahwa tiga dari empat $(75 \%)$ kasus kematian tenaga kesehatan RSUP Prof. Dr. R. D. Kandou Manado yang terpapar COVID-19 terdapat komorbid diabetes, empat dari empat $(100 \%)$ kasus terdapat komorbid hipertensi, dan satu dari empat kasus terdapat komorbid penyakit jantung.

Tabel 4. Jumlah kematian tenaga kesehatan RSUP Prof. Dr. R. D. Kandou Manado yang terpapar COVID-19 periode 2020-2021 menurut komorbid

\begin{tabular}{lcc}
\hline \multicolumn{1}{c}{ Komorbid } & Jumlah & \% \\
\hline Diabetes & 3 & 75 \\
Hamil & 0 & 0 \\
Hipertensi & 4 & 100 \\
HIV/AIDS & 0 & 0 \\
Jantung & 1 & 25 \\
Penyakit Ginjal Kronis & 0 & 0 \\
Penyakit Saraf & 0 & 0 \\
PPOK & 0 & 0 \\
Stroke & 0 & 0 \\
\hline
\end{tabular}

\section{BAHASAN}

Hasil penelitian ini mendapatkan empat kasus kematian tenaga kesehatan RSUP Prof. Dr. R. D. Kandou Manado yang terpapar oleh COVID-19 selama periode 2020-2021. Berdasarkan kelompok usia, didapatkan dominasi oleh kelompok usia di atas 55 tahun, yaitu sebanyak tiga dari empat kasus, dan satu kasus lainnya berusia 25-55 tahun. Usia yang lebih tua lebih rentan terhadap COVID19; hal ini dapat disebabkan oleh beberapa faktor seperti disfungsi multiorgan, menurunnya sistem imun, dan juga penyakit degeneratif lainnya. ${ }^{8}$

Berdasarkan jenis kelamin, tiga kasus di antaranya berjenis kelamin laki-laki dan satu kasus berjenis kelamin perempuan. Hal ini sejalan dengan sebuah penelitian metaanalisis yang menunjukkan bahwa laki-laki memiliki risiko kematian lebih besar, yaitu $1,86 \%$ daripada perempuan. ${ }^{9}$ Hal ini dapat disebabkan oleh angiotensin-converting enzyme-2 (ACE2) yang ekspresinya dikode oleh gen pada kromosom $\mathrm{X}$ yang lebih banyak didapatkan pada jenis kelamin perempuan. ${ }^{10}$ ACE2 memiliki peran menghambat angiotensin II (ANG II) yang dapat menyebabkan peningkatan tekanan darah, inflamasi, serta kerusakan jaringan dan pembuluh darah. ${ }^{11}$ COVID-19 masuk ke dalam tubuh manusia berikatan dengan ACE2 yang menyebabkan penurunan regulasi ACE2. Penurunan ACE2 berpengaruh pada meningkatnya ANG II yang kemudian terjadi peningkatan kerusakan jaringan. ${ }^{12}$

Berdasarkan kategori tenaga kesehatan, seluruh kasus merupakan tenaga medis (dokter umum dan dokter spesialis). Pada kategori perawat dan pekerja rumah sakit lainnya tidak didapatkan adanya kasus kematian. Beberapa faktor yang dapat memengaruhi hal ini, antara lain usia tenaga kesehatan, lamanya paparan tenaga kesehatan terhadap COVID-19, serta status kesehatan dari tenaga kesehatan itu sendiri.

Berdasarkan kategori komorbid, hipertensi menjadi komorbid dari semua kasus yang ada. Diabetes menjadi komorbid terbanyak kedua sebesar $75 \%$, dan komorbid terakhir ialah penyakit jantung pada satu kasus. Hal ini sejalan dengan penelitian dari 
Fakultas Kedokteran Universitas Gadjah Mada yang menyatakan komorbid hipertensi merupakan yang terbanyak sebesar $52,1 \%$, diabetes terbanyak kedua sebesar $33,6 \%$, dan penyakit jantung sebesar $20,9 \% .^{13}$

\section{SIMPULAN}

Gambaran kasus kematian tenaga kesehatan RSUP Prof. Dr. R. D. Kandou, Manado, yang terpapar COVID-19 selama periode 2020-2021 didominasi oleh usia di atas 55 tahun, jenis kelamin laki-laki, memiliki peran sebagai tenaga medis (dokter umum dan dokter spesialis), dengan komorbid terbanyak ialah hipertensi dan diabetes.

\section{Konflik Kepentingan}

Penulis menyatakan tidak terdapat konflik kepentingan dalam studi ini.

\section{DAFTAR PUSTAKA}

1. Susilo A, Rumende CM, Pitoyo CW, Santoso WD, Yulianti M, Herikurniawan $\mathrm{H}$, et al. Coronavirus disease 2019: tinjauan literatur terkini. Jurnal Penyakit Dalam Indonesia. 2020;7(1):45.

2. WHO Director-General's opening remarks at the media briefing on COVID-19 - 11 March 2020 [Internet]. [cited $2021 \mathrm{Dec}$ 15]. Available from: https://www.who. int/director-general/speeches/detail/ who-director-general-s-openingremarks-at-the-media-briefing-oncovid-19---11-march-2020

3. COVID Live Update: $271,281,757$ Cases and 5,332,371 Deaths from the Corona virus - Worldometer [Internet]. [cited 2021 Dec 15]. Available from: https://www. worldometers.info/coronavirus/

4. WHO. Coronavirus disease 2019 (COVID-19) Situation Report - 42 Data as reported by 10 AM CET 02 March $2020 \mathrm{H}$. World Health Organization [Internet]. 2020;14(6):e01218. Available from: https://www.who.int/docs/defaultsource/coronaviruse/situation-reports/ 20200302-sitrep-42-covid-19.pdf? sfvrsn=224c1add_2

5. Sebanyak 1.459 tenaga kesehatan meninggal akibat Covid-19 | Databooks [Internet]. [cited 2021 Aug 25]. Available from: https://databoks.katadata.co.id/datapubl ish/2021/07/21/sebanyak-1459-tenagakesehatan-meninggal-akibat-covid-19

6. Satria RMA, Tutupoho RV, Chalidyanto D. Analisis faktor risiko kematian dengan penyakit komorbid Covid-19. Jurnal Keperawatan Silampari. 2020;4(1):48-55.

7. Drew C, Adisasmita AC. Gejala dan komor-bid yang memengaruhi mortalitas pasien positif COVID-19 di Jakarta Timur, Maret-September 2020. Tarumanagara Medical Journal. 2021;3(3):274-83.

8. Rahmah DD. COVID-19 pada lanjut usia: tinjauan literatur. Wellness And Healthy Magazine [Internet]. 2021;3(1):37-41. Available from: https://doi.org/10. 30604/ well.149312021

9. Biswas M, Rahaman S, Biswas TK, Haque Z, Ibrahim B. Association of sex, age, and comorbidities with mortality in COVID19 patients: a systematic review and meta-analysis. Intervirology. 2021;64(1): 36-47.

10. Illah MNN. Analisis pengaruh komorbid, usia, dan jenis kelamin terhadap meningkatnya angka kematian pada masa pandemi COVID-19. Sosains. 2021;1(10):122833.

11. Ikawaty R. Dinamika interaksi reseptor ACE2 dan SARS-CoV-2 terhadap manifestasi klinis COVID-19. KELUWIH: Jurnal Kesehatan dan Kedokteran. 2020;1(2): 70-6.

12. Zhou $P$, Yang X lou, Wang XG, Hu B, Zhang $\mathrm{L}$, Zhang $\mathrm{W}$, et al. A pneumonia outbreak associated with a new coronavirus of probable bat origin. Nature. 2020; 579(7798):270-3.

13. Rahayu LAD, Admiyanti JC, Khalda YI, Ahda FR, Agistany NFF, Setiawati S, et al. Hipertensi, diabetes mellitus, dan obesitas sebagai faktor komorbiditas utama terhadap mortalitas pasien covid19: sebuah studi literatur. Jurnal Ilmiah Mahasiswa Kedokteran Indonesia (JIMKI). 2021;9(1):90-7. 